\title{
The Mediating Effect of Teachers' Workplace Spirituality between Emotional Intelligence and Change Readiness
}

\author{
Marc Romand A. Sumagpao ${ }^{1}$, Ida Gauran-Tudy ${ }^{2}$ \\ \{marcsumagpao@gmail.com ${ }^{1}$, tudyida@gmail.com ${ }^{2}$ \} \\ Cor Jesu College, Philippines ${ }^{1,2}$
}

\begin{abstract}
Unprecedented changes happen in the educational system that significantly affects the teachers. This challenge gained interest to the researchers and seek to link factors that could strengthen readiness among teachers. As a result, the goal of this descriptive-correlation study was to identify the role of workplace spirituality in moderating the relationship between emotional intelligence and transition readiness. A survey was administered to three hundred seven (307) public school teachers in Davao del Sur. Using Exploratory Factor Analysis, five factors were derived from workplace spirituality, three for emotional intelligence, and two for change readiness. Structural Equation Modelling and Sobel's test were used to determine the mediating effect. The findings showed that emotional intelligence significantly influence workplace and change readiness. However, only recently has it been discovered that workplace spirituality has little bearing on transition preparedness. Furthermore, the data demonstrated that teachers' workplace spirituality had a moderating influence on emotional intelligence and transition preparedness.
\end{abstract}

Keywords: Educational Planning and Management; Workplace Spirituality; Emotional Intelligence; Change Readiness; Structural Equation Model; Philippines

\section{Introduction}

The educational system is facing unprecedented changes driven by the arising challenges of health, economic, social, political, environmental, and technological developments. Resistance to change is widely experienced by schools as overwhelming advances are consistently appearing in the workplace and have caused problems to teachers. Burnout arose as teachers become overloaded with competencies and skills needed to adapt to constant changes that society goes through that aspires excellence in every learner [1]. Pressure, then, dominates in undertaking minor and major shifts, which would lead to teachers' resistance to change [2]. A research on the rise of transdisciplinary Science, Technology, Engineering, and Mathematics was undertaken in the United States of America (USA) in 2015. This brought adjustments to teachers and reported that the new practices require time and energy, which 
made them more overloaded. It also caused a certain amount of anxiety that made teachers reluctant to adapt to new practices [3].

The COVID-19 situation in 2020 affected nearly every area of life, especially education. The new normal education has had an impact on schools where face-to-face education is no longer used and has been replaced by other modes of learning such as online, modular, blended, and so on. On the preparedness of instructors in online teaching, an online survey was done in sixty-four (64) nations spanning elementary, middle, and university education. Given the short timeline for transitioning to online learning, the results revealed that teachers had limited time to upskill and prepare. In addition, the institution had a significant obligation to provide assistance and a shared understanding of standards for digital classroom instruction in designed to account for personal preparedness views [4].

In the Philippines, several educational reforms are implemented in 2019, such as continued K-12 program, free higher education, etc. However, due to these restructurings, teachers are loaded with so much work, and worse, they barely have time to teach. Therefore, the Department of Education (DepEd) acknowledges that there are still challenges that need to be addressed despite the educational changes [5]. With regard to the new normal system of education in 2020, several schools in the Philippines have adapted to different modes of delivery learning like online, modular, blended, educational TV, radio-based instruction, and homeschooling. A university in Laguna has adopted an online learning method. Teachers and students, on the other hand, were concerned about key changes such as knowledge and skill with technology, as well as their readiness to engage in this alternate learning modality. They have emphasized that the Commission on Higher Education (CHED) must organize a series of training sessions for instructors in order to enhance their capacity and provide them with knowledge and skills in the usage of flexible or blended learning [6].

In the Philippines, a research was done on the issues faced by public school instructors in the face of the epidemic. Due to a shortage of resources, the treatment of their pupils, and their submission and responsibilities, most instructors are severely challenged, stressed, and burned-out, according to the findings. Furthermore, instructors have battled with the digital age trend, since some of them have poor knowledge and skills in this area. As a consequence, due to a lack of resources, they are unable to do specific activities for students electronically, create an effective learning environment, or engage with students. Despite the stress and exhaustion, instructors obtain great experiences such as their enthusiasm and relationship in carrying out their responsibilities [7].

Emotions are an essential aspect of implementing change in one's organization. Hence, it must be revisited and re-examined. It is a vital tool in having a quality of life to improve performance in the workplace. It also aids in managing educational changes and even enables school administrators to promote good education and learning by gaining a better grasp about how peoples choices moods function and how they might positively or adversely influence their job $[8,9,10]$. Teachers need to cope with the different stressors such as workloads, role ambiguity, poor social support and classroom management problems, and even high demands in teaching and time pressures $[11,12]$.

Integrating emotion management in adapting to certain changes requires the understanding of oneself, work, and community. Spirituality in the workplace plays an essential role in various workplaces and schools. It is a fundamental element to boost employees' performance, and when they find meaning in their work, they become more engaged $[13,14]$. Workplace spirituality includes the employees' experiences of the meaning in work and community at work [15]. With low workplace spirituality, employees become stressed and anxious and this impacts their performance $[16,17]$. 
The education sector is experiencing unexpected changes that deem to sustain and maintain the quality education of the learners. Even though it was conducted in a single locality, this study is an essential tool in unveiling the factors that dominate teachers that hinder or motivate them to face challenges and changes in their workplace. The study also helped determine if one's workplace spirituality mediates between employees' emotional intelligence and change readiness. In addition, it also sought to determine the underlying factors of workplace spirituality, emotional intelligence, and change readiness. Moreover, this can become a basis for a broader scope of research and contribute to linking other related research.

\subsection{Theoretical Framework and Conceptual Framework}

This study was anchored on Goleman's (1995) [18] Emotional Intelligence Theory. Mayer and Salovey (2001) [19] describe emotional intelligence as the ability to perceive emotions, access and generate emotions to assist thoughts, understand emotions and emotional knowledge, and regulate emotions to promote emotional and intellectual growth. Emotional intelligence has its five (5) components which can affect one's performance at work and the readiness to take on different challenges.

These components are self-awareness, self-regulation, internal motivation, empathy, and social skills. For instance, a teacher who demonstrates self-awareness tends to be aware of his moods and how they affect others. In addition, exhibiting self-confidence and self-assessment may help teachers to weigh one's capabilities in taking on new challenges. Another example is when a teacher is self-regulated, he tends to have the ability to control impulses and moods and to think before doing specific actions. Therefore, if teachers practice self-regulation, they embody trustworthiness, integrity, and comfort with ambiguity and openness to change.

Moreover, teachers' positive attitude to face challenges and change would also relate to the theory of Spiritual Intelligence/Quotient of Selman and Selman [19] which stressed that spiritual intelligence would enable an individual to become less fearful, more accustomed to relying on himself, and more eager to face challenges and discomforts. They also emphasized that spiritual intelligence enables one to discriminate, moderate stiff rules with understanding and compassion, and understand their limits. Duchon and Plowman (2005) [20] identified three dimensions of workplace spirituality: inner life, meaningful work, and condition for the community.

These dimensions can be applied to teachers. For instance, if teachers bring their inner being to work, they tend to be more tolerant, patient, connected among others, goal-oriented, and accepting to the norms of the organization [21]. In the educational setting, unprecedented challenges and changes are met along the way. They could be caused by adapting to new schemes and alternative programs to sustain and maintain the quality of education. However, the school personnel, the teachers specifically, tend to become fearful of the unknown possibilities that may happen. Thus, applying spirituality in the workplace would make the dealing of changes less fearful and teachers become more confident and determined. The conceptual framework shown in Figure 1 illustrates the mediating effect of workplace spirituality between emotional intelligence and change readiness. The independent variable is emotional intelligence, while the dependent variable is change readiness. Workplace spirituality acts as the mediating variable between the two. 


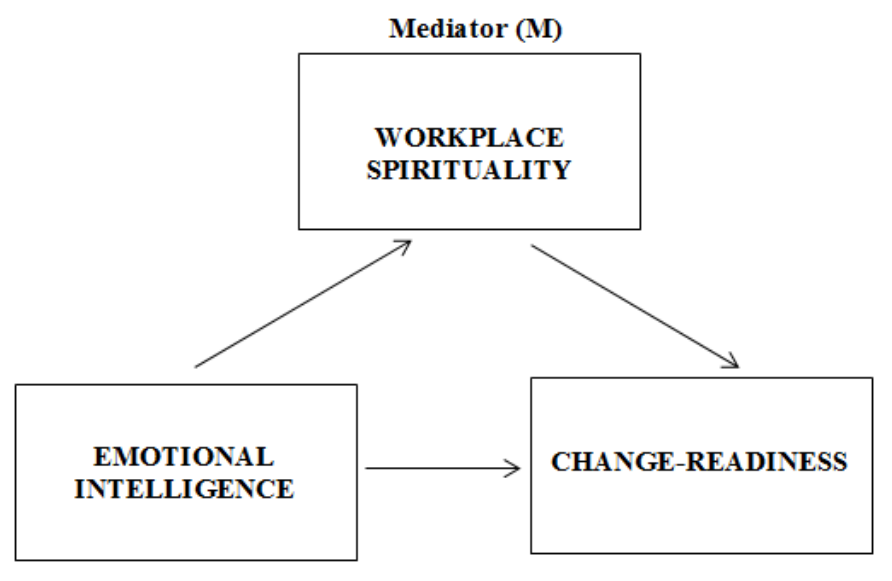

Independent Variable (IV)

Dependent Variable (DV)

Figure 1. Conceptual Framework of the Study

\subsection{Statement of the Problem}

This study aimed to determine the mediating effect of workplace spirituality between emotional intelligence and change-readiness among public school teachers in Davao del Sur. Specifically, it answered the following questions:

a. What are the underlying factors of workplace spirituality of teachers in Davao del Sur?

b. What are the underlying factors of emotional intelligence of teachers?

c. What are the underlying factors of change readiness of teachers?

d. Is there a mediating effect of workplace spirituality between emotional intelligence and change-readiness?

\subsection{Null Hypothesis}

A null hypothesis was formulated at 0.05 level of significance.

$\mathrm{Ho}_{1}$ : There is no significant influence of emotional intelligence of teachers to change readiness.

$\mathrm{Ho}_{2}$ : There is no significant influence of emotional intelligence of teachers to workplace spirituality.

$\mathrm{Ho}_{3}$ : There is no significant influence of workplace spirituality of teachers to change readiness.

$\mathrm{Ho}_{4}$ : Workplace spirituality has no mediating effect between emotional intelligence and change readiness.

\subsection{Significance of the Study}

The results are beneficial to the following: 
a. Department of Education Officials. As the head of the agency, they would be aware of the programs needed for the educators. They can also consider the underlying factors identified in the model as their basis of crafting programs for all teachers in the academe.

b. Superintendents and Supervisors. As division and district heads, they need to initiate programs that would help teachers on their personal effectiveness, not just mainly focusing on the intellectual aspects but should include the emotional and spiritual enhancements.

c. School Principals. As school leaders, they could design school-based programs that could enrich the teachers' readiness to change, such as seminars on self-management and interpersonal skills to make them efficient facilitators of the learners.

d. Teachers. As the prime target of this study, they need to have concrete assessment of their performance by giving weight on the underlying factors that may hinder or motivate them to face challenges and changes in the workplace.

e. Aspiring Teachers. They would be able to prepare themselves as future educators on the possible factors that can affect their readiness for any changes.

f. Future Researchers. They could utilize the results to venture related studies and explore more on other factors of the research that are not focused.

\subsection{Scope and Limitations}

The scope of this study was to determine the underlying factors of workplace spirituality, emotional intelligence, and change readiness. It also investigated the mediating effect of workplace spirituality between emotional intelligence and change readiness. This study was limited to the following. First, the respondents were only the public-school teachers of Davao del Sur. Second, newly appointed teachers were not included as respondents since all actions and activities are still new and fresh and they may have not experienced any changes yet. And lastly, considering the work and time the teachers have and the researchers' relentless efforts to retrieve the questionnaires, some teachers were not able to return their answers. Therefore, even without completing the entire population, the total number of respondents was also valid to be used in the data analysis.

\subsection{Definition of Terms}

To better understand the context of the study, these terms are defined conditionally and operationally:

a. Workplace spirituality refers to the ability of teachers to understand themselves and others, valuing their worth in the community, giving meaning and purpose to work, and realizing the importance of meditation and reflection in their day-to-day endeavors.

b. Emotional intelligence refers to how teachers manage their own emotions and the emotions of others.

c. Change readiness refers to teachers' effectiveness and adaptability in dealing with change and how they deal with unexpected workplace challenges.

\section{Methodology}

This chapter presents the methods that were used in conducting the study. Through this, the researcher can give a clearer and reliable procedure in extracting and formulating the 
results. Moreover, the research design, the respondents, the sampling, measures, the data gathering and analysis procedure with the help of tools and experts are discussed.

\subsection{Research Design}

The descriptive correlational approach was used to investigate the role of workplace spirituality in moderating the relationship between change readiness and emotional intelligence in school teachers. This study strategy is used to acquire information on the current status of the phenomena to characterize "what existing" with respect to variables or circumstances in a scenario, according to Calderon and Gonzales (1993) [58]. It's not an experiment, but it's about connections. Relevant variables are simply chosen for an investigation of their connection since the events or circumstances have already occurred or existed.

\subsection{Respondents and Setting}

The respondents of this study were the 307 public elementary school teachers. The data for this research was collected in a specific locality in Davao del Sur. The elementary schools that were chosen for this research are located in a medium-sized municipality. Table 1 presents that there were 307 total respondents in the twenty four (24) public elementary schools who answered the survey questionnaire for this study.

Table 1. Distribution of Respondents

\begin{tabular}{cc}
\multicolumn{2}{c}{ Table 1. Distribution of Respondents } \\
\hline School & Number of Respondents \\
\hline Public Elementary School 1 & 7 \\
Public Elementary School 2 & 12 \\
Public Elementary School 3 & 8 \\
Public Elementary School 4 & 5 \\
Public Elementary School 5 & 8 \\
Public Elementary School 6 & 7 \\
Public Elementary School 7 & 7 \\
Public Elementary School 8 & 8 \\
Public Elementary School 9 & 43 \\
Public Elementary School 10 & 11 \\
Public Elementary School 11 & 8 \\
Public Elementary School 12 & 7 \\
Public Elementary School 13 & 8 \\
Public Elementary School 14 & 17 \\
Public Elementary School 15 & 11 \\
Public Elementary School 16 & 20 \\
Public Elementary School 17 & 7 \\
Public Elementary School 18 & 21 \\
Public Elementary School 19 & 35 \\
Public Elementary School 20 & 12 \\
Public Elementary School 21 & 12 \\
Public Elementary School 22 & 8 \\
Public Elementary School 23 & 10 \\
Public Elementary School 24 & 15 \\
Total & 307 \\
\hline
\end{tabular}




\subsection{Sampling}

The researchers employed a complete enumeration in which all members of the whole population were measured. Complete enumeration was used since all teachers were being surveyed in the same municipality. A total of 307 respondents were given a survey questionnaire.

\subsection{Measures}

Workplace Spirituality, Emotional Intelligence, and Change Readiness data were collected using a series of validated questionnaires. Respondents were given this in the form of questionnaires. Each questionnaire comprises of statements or questions that were responded on a five-point Likert scale ranging from strongly disagree (1), disagree (2), neither agree nor disagree (3), agree (4), very agree (5), and strongly agree (6). (5). Content validation and pilot testing were performed on these surveys. The results show that all three variables reached and exceeded the .70 Cronbach alpha. Specifically, Workplace Spirituality has .814 Cronbach alpha, Emotional Intelligence has a .886 Cronbach alpha, and Change Readiness has .813 Cronbach alpha.

Three different questionnaires were used in the study. First was the Workplace Spirituality (WS) Scale questionnaire. This is consist of 30-item questions adapted from Ashmos and Duchon(2000). The scales measure the WS in terms of conditions for community, meaning at work, inner life, blocks to spirituality, personal responsibility, positive connections with other individuals, contemplation. The second was the Emotional Intelligence (EI) Scale questionnaire. This has 30-item questions adapted from Leadership Toolkit questionnaires. The EI scale measures self-awareness, managing emotions, motivating oneself, empathy, and social skills. Lastly, was the Change Readiness (CR) scale questionnaire. This was adapted from Purdue (2012), which has 30 items. The scale measures CR in terms of resourcefulness, optimism, adventurousness, passion/drive, adaptability, confidence, and tolerance for ambiguity.

\subsection{Procedure}

The following were the steps followed in gathering the data:

a. The researchers wrote a request letter to conduct the study to the Division of Davao del Sur. It was then approved and signed by the Schools Division Superintendent.

b. They also asked permission from the District Supervisors in both districts (North and South) in Magsaysay Davao del Sur. When the approval was granted, they asked permission from the school principals to survey on the specified scheduled date. They adhered to the safety protocols such as wearing face shield and face mask, hand washing and temperature checking before entering the vicinity.

c. When permission was given to conduct the study, the researchers then administered the survey to the teachers. To have less contact among teachers, questionnaires were only given to the school principals with clear instruction coming from the researchers. Questionnaires were later given to the teachers and were filled out, in all honesty.

d. The school principal submitted the questionnaires to the district office. However, some schools failed to give it to the district office, so the researchers went to the specified schools. 
e. Answers were tallied, analyzed and interpreted by the researchers with the aid of the statistician.

\subsection{Data Analysis}

a. Exploratory Factor Analysis (EFA). This was used to determine the underlying factors of workplace spirituality, emotional intelligence, and change readiness. This was done by reducing data in to a smaller set of summary variables and explores the underlying variables of the phenomena [59].

b. Confirmatory Factor Analysis (CFA). CFA using Structural Equation Modelling (SEM) was used to test and assess how the relations between latent and observed indicator variables affect each other in various ways. CFA also tests the hypothesis and finds out if the relationship between observed variables and their underlying latent constructs exists. It also helps to determine if it fits to the model presented [60].

\section{Results and Discussion}

This chapter shows the results and discussion of the study. The data were analyzed using Explanatory Factor Analysis (EFA) and Structural Equation Modeling. First, the presentation of results shows the underlying factors of the three variables namely; Workplace Spirituality, Emotional Intelligence, and Change Readiness. Second, the results of the mediating of Workplace Spirituality between Emotional Intelligence and Change Readiness were discussed.

\subsection{Results}

\subsubsection{Underlying Factors of Workplace Spirituality}

Table 2 presents the Kaiser-Meyer-Olkin (KMO) and Bartlett's Test for Workplace Spirituality. Exploratory Factor Analysis (EFA) was used for the Workplace Spirituality with 30 items. The aim of this analysis was the reduction of data removing highly correlated items and grouping uncorrelated items into underlying or latent relationships. In identifying the number of factors, several tests were performed including Kaiser-Meyer-Olkin (KMO) criterion, screen plot of eigen values, and other analyses. KMO is used to measure sampling adequacy. In the first run of EFA, the results yielded a KMO of .867 which is within the acceptable value. It means that the sample size qualifies for factor analysis. Another supporting information is the Bartlertt's Test of Sphericity with the

Table 2. KMO and Barletts' Test for Workplace Spirituality

\begin{tabular}{ccc}
\hline \multicolumn{3}{c}{ KMO and Bartlett's Test } \\
\hline Kaiser-Meyer-Olkin Measure of Sampling Adequacy & .867 \\
Bartlett's Test of Sphericity & Approx. Chi-Square & 4022.450 \\
& Df & 435 \\
sig. & .000 \\
\hline
\end{tabular}

p-value of 0.000 which means that there is at least one significant correlation between two items. The Principal Components Analysis summaries show Eigen values and Percent Variance Explained, seven (7) components/factors were identified and a $61.314 \%$ total variance was explained. Initially, Oblimin Rotation was used to determine if the factors are 
orthogonal or oblique. Looking at the Component Correlation Matrix, there were coefficient lesser than 0.5 meaning factors are strongly correlated; therefore, these are oblique. Hence, a Viramax Rotation was applied.

The final analyses, as presented in Table 2 yielded a KMO value of .867 which is again within the acceptable value. It means that the sample size qualifies for factor analysis. Another supporting data is the Barlett's Test of Sphericity with a p-value of .000 which means that there is at least one significant correlation between two items. Table 3 shows the results of the analysis, which yielded six (6) factors and equivalent percentage of variance explained. Factor 1 had the highest total variance explained with a value of $27.796 \%$, followed by Factor 2 with a value of $12.042 \%$, Factor 3 with a value of $5.455 \%$, Factor 4 with a value of $4.882 \%$, Factor 5 with a value of $3.794 \%$, and Factor 6 has the lowest total variance explained with a value of $3.699 \%$. The cumulative percentage is $61.314 \%$ and is within the acceptable range.

Table 3. Principal Components Analysis Summaries: Eigenvalues and Percent of Variance

\begin{tabular}{cccc}
\hline Factor & Eigenvalue & \% of Variance & Cumulative \% \\
\hline 1 & 8.339 & 27.796 & 27.796 \\
2 & 3.613 & 12.042 & 39.838 \\
3 & 1.637 & 5.455 & 45.293 \\
4 & 1.464 & 4.882 & 50.175 \\
5 & 1.138 & 3.794 & 53.969 \\
6 & 1.110 & 3.699 & 57.667 \\
7 & 1.094 & 3.646 & 61.314 \\
\hline
\end{tabular}

Table 4 presents the Explanatory Factor Analysis Pattern Coefficient Matrix wherein the Rotated Component Matrix, Factor 1 has identified eight (8) items namely, WS17, WS18, WS19, WS24, WS29, WS23, WS20, and WS21. Factor 2 has identified five (5) items namely, WS25, WS26, WS30, WS7, and WS4. Factor 3 has identified five (5) items namely, WS15, WS14, WS11, WS13, and WS10. Factor 4 has identified five (5) items namely, WS3, WS2, WS5, WS22, and WS6. Factor 5 has four (4) items namely, WS12, WS9, WS1, and WS8. Factor 6 has two (2) items namely WS27 and WS28. Factor 7 has only one (1) item which is WS16. The items in each factors show that they are strongly related and this also means that what they are measuring is relatively the same thing. After determining the factors and their corresponding items, reliability test was performed to determine the reliability of the new factors. Results revealed that Factors 1, 2,3,4,5, and 6 exceed the threshold of .840, .856, .752, $.720, .665$, and .758 , respectively. However, Factor 7 was excluded since it did not pass the .70 Cronbach Alpha.

Table 4. Exploratory Factor Analysis-Pattern Coefficient Matrix

\begin{tabular}{|c|c|c|c|c|c|c|c|c|}
\hline & & \multirow{3}{*}{$\begin{array}{l}\text { Cronbach } \\
\text { Alpha }\end{array}$} & \multicolumn{5}{|c|}{ Factors } & \multirow{3}{*}{$\begin{array}{c}6 \\
.758 \\
\end{array}$} \\
\hline & & & 1 & 2 & 3 & 4 & 5 & \\
\hline & & & .840 & .856 & .752 & .720 & .665 & \\
\hline WS17. & $\begin{array}{l}\text { At work, we work together } \\
\text { to resolve conflict in a } \\
\text { positive way. }\end{array}$ & & .643 & & & & & \\
\hline WS18. & I am evaluated fairly here. & & .630 & & & & & \\
\hline WS19. & $\begin{array}{l}\text { I am encouraged to take } \\
\text { risks at work. }\end{array}$ & & .604 & & & & & \\
\hline WS24. & $\begin{array}{l}\text { I care about the spiritual } \\
\text { health of my coworkers. }\end{array}$ & & .596 & & & & & \\
\hline
\end{tabular}




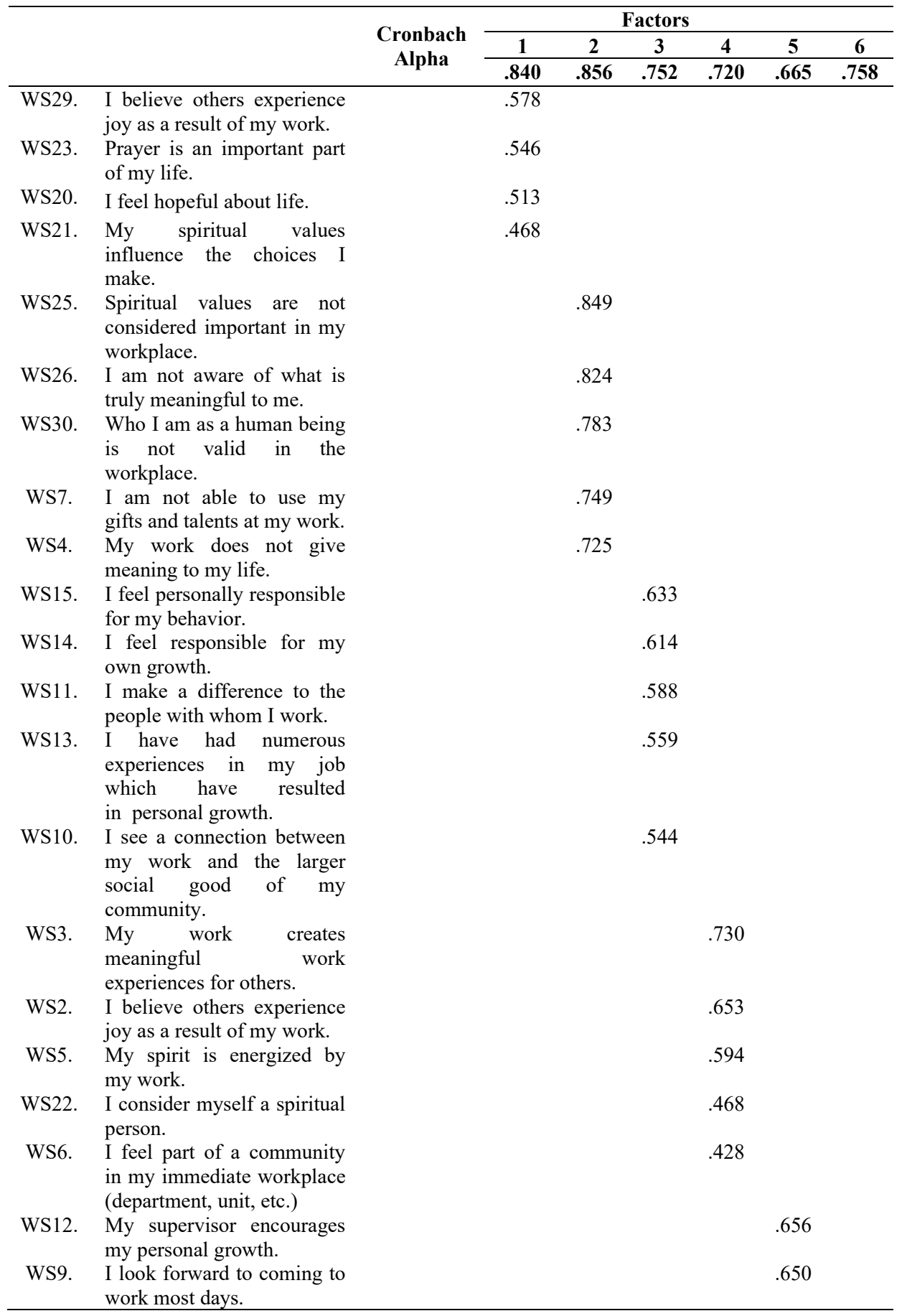




\begin{tabular}{|c|c|c|c|c|c|c|c|c|}
\hline & & \multirow{3}{*}{$\begin{array}{l}\text { Cronbach } \\
\text { Alpha }\end{array}$} & \multicolumn{5}{|c|}{ Factors } & \multirow{3}{*}{$\begin{array}{c}6 \\
.758\end{array}$} \\
\hline & & & 1 & 2 & 3 & 4 & 5 & \\
\hline & & & .840 & .856 & .752 & .720 & .665 & \\
\hline WS1. & $\begin{array}{l}\text { I experience joy in my } \\
\text { work. }\end{array}$ & & & & & & .613 & \\
\hline WS8. & $\begin{array}{l}\text { The work I do is connected } \\
\text { to what I think is important } \\
\text { in life. }\end{array}$ & & & & & & .453 & \\
\hline WS27. & $\begin{array}{l}\text { Meditation is an important } \\
\text { part of my life. }\end{array}$ & & & & & & & $\begin{array}{c}.77 \\
1\end{array}$ \\
\hline WS28. & $\begin{array}{l}\text { Personal reflection is an } \\
\text { important part of my life. }\end{array}$ & & & & & & & $\begin{array}{c}.73 \\
4 \\
\end{array}$ \\
\hline
\end{tabular}

Looking at the items loaded per factor in table 4, Factor 1 is named WorkSpirit1 or Understanding Oneself and Others since the items are related to how teachers assess themselves about life and work and how it affects the community around them. Factor 2 is named WorkSpirit2 or Self-awareness since the items are dealing with the awareness of having meaningful life at work, and spirituality is considered valuable in the workplace. Factor 3 is called WorkSpirit3 or Responsibility of Oneself at Work since the items are centered on keeping in control of growth and development and stressing that one's behavior and personal commitment can affect your perspective in work and life. Factor 4 is named WorkSpirit4 or Giving Meaning since the items are focused on the effect of one's work and community on their spirituality. Factor 5 is named WorkSpirit5 or Purpose and Personal Growth since items are loaded with reasons for going to work and benefit oneself and others. Factor 6 is named WorkSpirit6 or Meditation and Reflection since items are focused on the importance of meditation and personal reflection to teachers' daily lives.

\subsubsection{Underlying Factors of Emotional Intelligence}

Table 5 illustrates the KMO and Bartlett's Test for Emotional Intelligence. EFA was used for the Emotional Intelligence with 30 items. The aim of this analysis was the reduction of data removing highly correlated items and grouping uncorrelated items into underlying or latent relationships. In identifying the number of factors, several tests were performed including Kaiser-Meyer-Olkin (KMO) criterion, screen plot of eigen values, and other analyses. KMO is used to measure sampling adequacy. In the first run of EFA, the results yielded a KMO of .861 which is within the acceptable value. It means that the sample size qualifies for factor analysis. Another supporting information is the Bartlertt's Test of Sphericity with the p-value of 0.000 which means that there is at least one significant correlation between two items.

Table 5. KMO and Barletts' Test for Emotional Intelligence

\begin{tabular}{ccc}
\hline \multicolumn{3}{c}{ KMO and Bartlett's Test } \\
\hline Kaiser-Meyer-Olkin Measure of Sampling Adequacy & .861 \\
Bartlett's Test of Sphericity & Approx. Chi-Square & 3287.347 \\
& df & 435 \\
& sig. & .000 \\
\hline
\end{tabular}

Looking at the Principal Components Analysis summaries showing Eigen values and Percent Variance Explained, nine (9) components/factors were identified and a $63.737 \%$ total 
variance was explained. Initially, Oblimin Rotation was used to determine if the factors are orthogonal or oblique. Looking at the Component Correlation Matrix, there were coefficient lesser than 0.5 meaning factors are strongly correlated; therefore, these are oblique. Hence, a Viramax Rotation was applied. The final analyses, as presented in Table 5 yielded a KMO value of .861 which is again within the acceptable value. It means that the sample size qualifies for factor analysis. Another supporting data is the Barlett's Test of Sphericity with a p-value of .000 which means that there is at least one significant correlation between two items. Table 6 shows the results of the analysis, which yielded six (5) factors and equivalent percentage of variance explained. Factor 1 had the highest total variance explained with a value of $27.252 \%$, Factor 2 was the second with a value of $7.016 \%$, Factor 3 was the third with a value of $5.747 \%$, Factor 4 was the fourth with a value of $4.785 \%$, and Factor 5 was the fifth with a value of $4.266 \%$. The cumulative percentage is $63.737 \%$ and is within the acceptable range.

Table 6. Principal Components Analysis Summaries: Eigenvalues and Percent of Variance

\begin{tabular}{cccc}
\hline Factor & Eigenvalue & \% of Variance & Cumulative $\%$ \\
\hline 1 & 8.176 & 27.252 & 27.252 \\
2 & 2.105 & 7.016 & 34.268 \\
3 & 1.724 & 5.747 & 40.015 \\
4 & 1.436 & 4.785 & 44.800 \\
5 & 1.280 & 4.266 & 49.066 \\
6 & 1.194 & 3.979 & 53.045 \\
7 & 1.121 & 3.738 & 56.783 \\
8 & 1.052 & 3.505 & 60.288 \\
9 & 1.035 & 3.449 & 63.737 \\
\hline
\end{tabular}

Table 7 presents the Explanatory Factor Analysis Pattern Coefficient Matrix wherein the Rotated Component Matrix, Factor 1 has identified eight (8) items namely, EI14, EI15, EI29, EI13, EI21, EI9, EI19, and EI18. Factor 2 has identified four (4) items namely, EI25, EI24, EI23, and EI12. Factor 3 has identified three (3) items namely, EI26, EI7, and EI10. Factor 4 has identified three (3) items namely EI27, EI28, and EI30. Factor 5 has identified four (4) items namely EI22, EI16, EI20, and EI17. Factor 6 has identified three (3) items namely EI1, EI2, and EI3. Factor 7 has two (2) items namely EI18 and EI11. Factor 8 has two (2) items namely EI16 and EI15. Factor 9 has only one (1) item which is EI14. The items in each factors show that they are strongly related and this also means that what they are measuring is relatively the same thing.

After determining the factors and their corresponding items, reliability test was performed to determine the reliability of the new factors. Results revealed that Factors 1,2,3,4, and 5 exceed the threshold of $.770, .735, .684, .711$, and .690 , respectively. However, Factor 6 , Factor 7, Factor 8, and Factor 9 were excluded since they did not pass the .70 Cronbach Alpha. Looking at the items loaded per factor in table 7, Factor 1 is named Emol or SelfAwareness since the items loaded focus on having the ability to recognize and understand oneself. Factor 2 is named Emo2 or Self-regulation since the items loaded are related to the ability to maintain emotions stable even with an adverse climate that can be encountered. Factor 3 is named Emo3 or Interpersonal Effectiveness since items loaded to focus on handling others' problems effectively. Factor 4 is named Emo4 or Motivating Oneself and Others since the items are mainly focused on using emotions to move and guide towards one's goal. Finally, factor 5 is named Emo5 or Openness since the items loaded are related to being open and understanding other individuals' differences and decisions in life. 
Table 7. Exploratory Factor Analysis-Pattern Coefficient Matrix

\begin{tabular}{|c|c|c|c|c|c|c|c|}
\hline & $x^{2}+2$ & \multirow{3}{*}{$\begin{array}{l}\text { Cronbach } \\
\text { Alpha }\end{array}$} & \multicolumn{5}{|c|}{ Factors } \\
\hline & & & 1 & 2 & 3 & 4 & 5 \\
\hline & & & .770 & .735 & .684 & .711 & .690 \\
\hline EI14. & $\begin{array}{l}\text { I always know when I'm being } \\
\text { unreasonable. }\end{array}$ & & .642 & & & & \\
\hline EI15. & $\begin{array}{l}\text { I believe you should do the difficult } \\
\text { things first. }\end{array}$ & & .586 & & & & \\
\hline EI29. & $\begin{array}{l}\text { Reasons for disagreements are always } \\
\text { clear to me. }\end{array}$ & & .564 & & & & \\
\hline EI13. & $\begin{array}{l}\text { I can usually understand why people } \\
\text { are being difficult towards me and can } \\
\text { tell if someone is not happy with me. }\end{array}$ & & .535 & & & & \\
\hline EI21. & $\begin{array}{l}\text { I rarely worry about work or li } \\
\text { fe in general. }\end{array}$ & & .511 & & & & \\
\hline EI9. & $\begin{array}{l}\text { I always meet deadlines and never } \\
\text { waste time. }\end{array}$ & & .501 & & & & \\
\hline EI19. & $\begin{array}{l}\text { Delayed gratification is a virtue that I } \\
\text { hold to. }\end{array}$ & & .453 & & & & \\
\hline EI18. & $\begin{array}{l}\text { I do not let stressful situations or } \\
\text { people affect me once I have left work. }\end{array}$ & & .420 & & & & \\
\hline EI25. & $\begin{array}{l}\text { I can suppress my emotions when I } \\
\text { need to. }\end{array}$ & & & .803 & & & \\
\hline EI24. & $\begin{array}{l}\text { I can let anger 'go' quickly so that it no } \\
\text { longer affects me. }\end{array}$ & & & .691 & & & \\
\hline EI23. & $\begin{array}{l}\text { I see working with difficult people as } \\
\text { simply a challenge to win them over. }\end{array}$ & & & 649 & & & \\
\hline EI12. & Difficult people do not annoy me. & & & .472 & & & \\
\hline EI26. & $\begin{array}{l}\text { I am good at reconciling differences } \\
\text { with other people. }\end{array}$ & & & & .729 & & \\
\hline EI7. & $\begin{array}{l}\text { I am excellent at empathizing with } \\
\text { someone else's problem. }\end{array}$ & & & & .633 & & \\
\hline EI10. & $\begin{array}{l}\text { I am good at adapting and mixing with } \\
\text { a variety of people. }\end{array}$ & & & & .599 & & \\
\hline EI27. & I know what makes me happy. & & & & & .805 & \\
\hline EI28. & $\begin{array}{l}\text { Motivation has been the key to my } \\
\text { success. }\end{array}$ & & & & & .756 & \\
\hline EI30. & $\begin{array}{l}\text { I generally build solid relationships } \\
\text { with those I work with. }\end{array}$ & & & & & .523 & \\
\hline EI22. & $\begin{array}{l}\text { I can understand why my actions } \\
\text { sometimes offend others. }\end{array}$ & & & & & & .607 \\
\hline EI16. & $\begin{array}{l}\text { Other individuals are not 'difficult' just } \\
\text { 'different. }\end{array}$ & & & & & & .600 \\
\hline EI20. & $\begin{array}{l}\text { I like to ask questions to find out what } \\
\text { it is important to people. }\end{array}$ & & & & & & .593 \\
\hline EI17. & $\begin{array}{l}\text { Awareness of my own emotions is } \\
\text { very important to me at all times. }\end{array}$ & & & & & & .499 \\
\hline
\end{tabular}

\subsubsection{Underlying Factors of Change Readiness}


Table 8 shows the Kaiser-Meyer-Olkin (KMO) and Bartlett's Test for Change Readiness. Exploratory Factor Analysis (EFA) was used for the Change Readiness with 30 items. The aim of this analysis was the reduction of data removing highly correlated items and grouping uncorrelated items into underlying or latent relationships. In identifying the number of factors, several tests were performed including Kaiser- Meyer-Olkin (KMO) criterion, screen plot of eigen values, and other analyses. KMO is used to measure sampling adequacy. In the first run of EFA, the results yielded a KMO value of .816 which is within the acceptable value. It means that the sample size qualifies for factor analysis.

Table 8.KMO and Barletts' Test for Change Readiness

\begin{tabular}{ccc}
\hline \multicolumn{3}{c}{ KMO and Bartlett's Test } \\
\hline Kaiser-Meyer-Olkin Measure of Sampling Adequacy & .816 \\
Bartlett's Test of Sphericity & Approx. Chi-Square & 2500.039 \\
& Df & 435 \\
& sig. & .000 \\
\hline
\end{tabular}

Another supporting information is the Bartlertt's Test of Sphericity with the p-value of 0.000 which means that there is at least one significant correlation between two items. Looking at the Principal Components Analysis summaries showing Eigen values and Percent Variance Explained, three (3) components/factors were identified and a $56.752 \%$ total variance was explained. Initially, Oblimin Rotation was used to determine if the factors are orthogonal or oblique. Looking at the Component Correlation Matrix, there were coefficient lesser than 0.5 meaning factors are strongly correlated; therefore, these are oblique. Hence, a Viramax Rotation was applied. The final analyses, as presented in Table 8 yielded a KMO value of .816 which is again within the acceptable value. It means that the sample size qualifies for factor analysis. Another supporting data is the Barlett's Test of Sphericity with a p-value of .000 which means that there is at least one significant correlation between two items.

Table 9. Principal Components Analysis Summaries: Eigenvalues and Percent of Variance

\begin{tabular}{cccc}
\hline Factor & Eigenvalue & \% of Variance & Cumulative \% \\
\hline 1 & 6.003 & 20.010 & 20.010 \\
2 & 3.065 & 10.218 & 30.228 \\
3 & 1.704 & 5.680 & 35.908 \\
4 & 1.512 & 5.039 & 40.947 \\
5 & 1.349 & 4.496 & 45.444 \\
6 & 1.183 & 3.945 & 49.389 \\
7 & 1.161 & 3.869 & 53.258 \\
8 & 1.048 & 3.494 & 56.752 \\
\hline
\end{tabular}

Table 9 shows the results of the analysis, which yielded three (3) factors and equivalent percentage of variance explained. Factor 1 had the highest total variance explained with a value of $20.010 \%$, followed by Factor 2 with a value of $10.218 \%$, and the lowest Factor 3 with a value of $5.680 \%$. The cumulative percentage is $35.908 \%$ and is within the acceptable range.

Table 10 illustrates the Explanatory Factor Analysis Pattern Coefficient Matrix wherein the Rotated Component Matrix, Factor 1 has identified five (5) items namely, CR27, CR23, CR24, CR26, and CR17. Factor 2 has five (5) items namely, CR13, CR6, CR10, CR9, and CR15. Factor 3 has five (5) items namely, CR22, CR28, CR21, CR22, and CR30. Factor 4 has three (3) items namely, CR8, CR7, and CR20. Factor 5 has three (3) items namely, CR1, CR2, and CR11. Factor 6 has three (3) items namely, CR5, CR4, and CR3. Factor 7 has two 
(2) items namely, CR19 and CR18. Factor 8 has three (3) items namely, CR14, CR12, and CR25. The items in each factor are strongly related. It also means that what they are measuring is relatively the same thing. After determining the factors and their corresponding items, reliability test was performed to determine the reliability of the new factors. Results revealed that Factors 1, 2, and 3 exceed the threshold of .721, .684, and .721, respectively. However, Factors $4,5,6,7$, and 8 were excluded since they did not pass the .70 Cronbach Alpha.

Table 10. Exploratory Factor Analysis-Pattern Coefficient Matrix

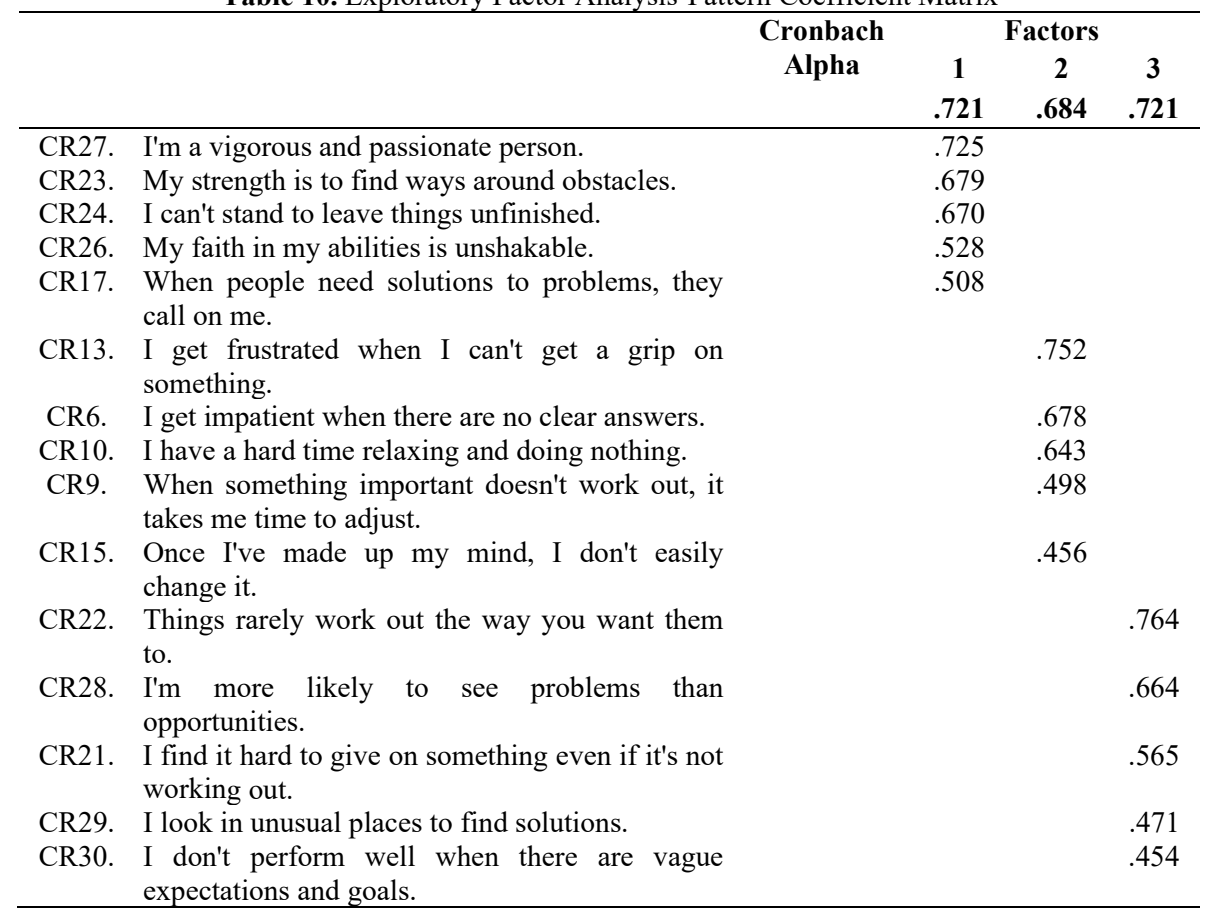

Looking at the items loaded per factor in table 10, Factor 1 is named Change1 or Selfefficacy since the items loaded are related to recognizing the opportunities and possibilities and gaining that drive to be unaffected amidst changes that happened. Factor 2 is named Change2 or Adaptability since the items focus on how teachers react to specific changes and how they deal with them. Finally, factor 3 is named Change 3 or Uncertainty since the items point out the possibilities that change may become terrifying and uncomfortable, and the feeling of uncertainty may dominate most especially when a person is unaware of what will happen.

\subsubsection{Mediating Effect of Workplace Spirituality between Emotional Intelligence and Change Readiness}

The postulated model was subjected to Confirmatory Factor Analysis (CFA). The data from EFA was entered into AMOS to find the optimal model by examining the measurements' validity and reliability, as well as many fit indices. The maximum likelihood method was 
utilized to estimate the minimization history, standardized estimates, residual moments, and modification indices. The appropriate degree of fit was attained after model specification. Table 11 shows the values of different fit indices- Absolute Fit, Relative Fit and Parsimony Fit of both hypothesized and modified model with the threshold values.

Table 11. Fit Indices for the Hypothesized and Measurement Model

\begin{tabular}{|c|c|c|c|c|c|}
\hline Fit Index & Symbol & $\begin{array}{c}\text { Hypothesized } \\
\text { Model }\end{array}$ & $\begin{array}{c}\text { Modified } \\
\text { Model }\end{array}$ & $\begin{array}{c}\text { Threshold } \\
\text { Values }\end{array}$ & Source \\
\hline \multicolumn{6}{|c|}{ Absolute Fit Indices } \\
\hline $\begin{array}{l}\text { Degrees of } \\
\text { Freedom }\end{array}$ & $\mathrm{Df}$ & 74 & 30 & & \\
\hline Chi-Square & $\chi^{2}$ & 428.178 & 55.877 & $\begin{array}{l}<2 \text { or } 3 \text { - Good } \\
\text { and }<5- \\
\text { permissible }\end{array}$ & Kline (2005) \\
\hline $\begin{array}{l}\text { Chi- } \\
\text { Square/Degree } \\
\text { of Freedom }\end{array}$ & $\begin{array}{c}\chi^{2 / d f} \\
(\mathrm{CMIN} / \mathrm{df})\end{array}$ & 5.786 & 1.863 & 2 to 5 & $\begin{array}{l}\text { Marsh and } \\
\text { Hocevar (1985) }\end{array}$ \\
\hline $\begin{array}{l}\text { Probability of } \\
\text { CMIN }\end{array}$ & $\mathrm{P}$ & .000 & .002 & $>0.05$ & \\
\hline $\begin{array}{l}\text { Goodness of } \\
\text { Fit Index }\end{array}$ & GFI & .821 & .966 & $\begin{array}{l}0 \text { (no fit)-1 } \\
\text { (perfect } \\
\text { fit)(Should be } \\
>0.90 \text { ) }\end{array}$ & Byrne (1994) \\
\hline $\begin{array}{l}\text { Root Mean } \\
\text { Square } \\
\text { Residual }\end{array}$ & RMR & .062 & .011 & $<0.05$ & Kline (2005) \\
\hline $\begin{array}{l}\text { Root Mean } \\
\text { Square Error of } \\
\text { Approximation }\end{array}$ & RMSEA & .125 & .053 & $<0.6$ & $\begin{array}{l}\text { Hu and Bentler } \\
\text { (199) }\end{array}$ \\
\hline \multicolumn{6}{|c|}{ Relative Fit Indices } \\
\hline $\begin{array}{l}\text { Normed Fit } \\
\text { Index }\end{array}$ & NFI & .734 & .943 & $>0.90 />0.95$ & $\begin{array}{l}\text { Byrne } \\
\text { (1994)/Schumace } \\
\text { r\& Lomax } \\
(2004)\end{array}$ \\
\hline $\begin{array}{l}\text { Tucker-Lewis } \\
\text { Index }\end{array}$ & TLI & .713 & .960 & $>0.90 />0.95$ & $\begin{array}{l}\text { Byrne } \\
\text { (1994)/Schumace } \\
\text { r\& Lomax } \\
(2004)\end{array}$ \\
\hline $\begin{array}{l}\text { Comparative } \\
\text { Fit Index }\end{array}$ & CFI & .767 & .972 & $>0.85 />0.90$ & Byrne (1994) \\
\hline \multicolumn{6}{|c|}{ Parsimony Fit Indices } \\
\hline Parsimony & PCFI & .624 & .670 & 0 (no fit)-1 & Mulaik et al. \\
\hline $\begin{array}{l}\text { Comparative } \\
\text { Fit Index }\end{array}$ & & & & (perfect fit) & (1989) \\
\hline $\begin{array}{l}\text { Parsimony } \\
\text { Nomred Fit } \\
\text { Index }\end{array}$ & PNFI & .597 & .649 & $\begin{array}{l}0 \text { (no fit)-1 } \\
\text { (perfect fit) }\end{array}$ & $\begin{array}{l}\text { Mulaik et al. } \\
\text { (1989) }\end{array}$ \\
\hline
\end{tabular}

In the hypothesized model (Figure 2) the chi-square was very large at 428.178 , which was understandable giving the large sample size. Also, the other indices showed the following values- $\mathrm{CMIN} / \mathrm{df}=5.786, \mathrm{GFI}=0.821, \mathrm{RMSEA}=0.125, \mathrm{NFI}=0.734, \mathrm{CFI}=0.767 \mathrm{TLI}=$ 
$0.713, \mathrm{PCFI}=0.624$ and PNFI $=0.597$. Some values suggested that the data did not fit well with the hypothesized model. Also, there were very high covariance values in the modification index between some of observed variables.

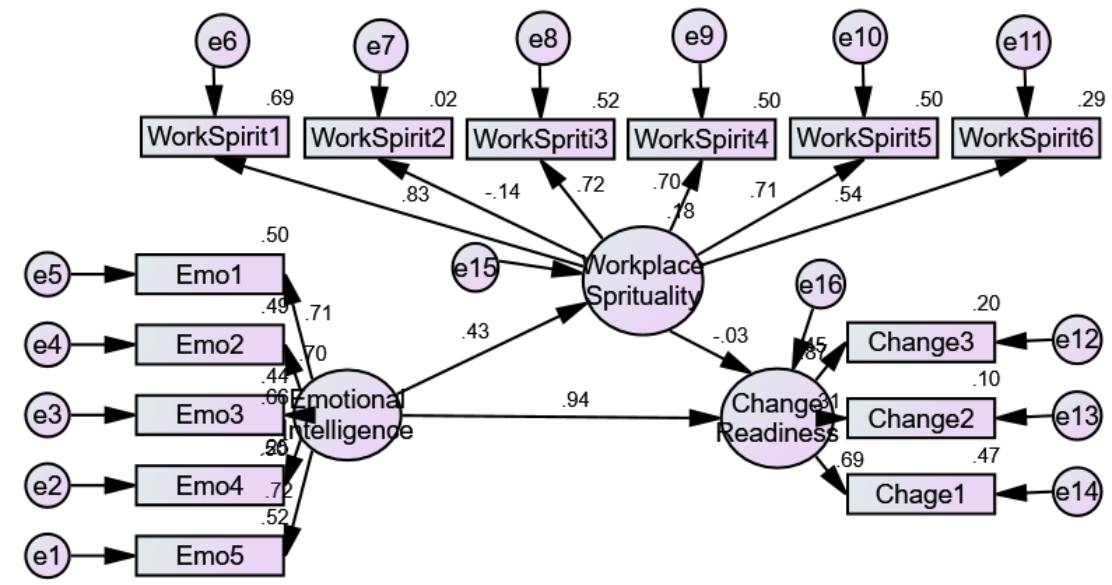

Fig. 2. Hypothesized Model

With the goodness of fit not achieved, re-specification was needed of the hypothesized model based on the criteria set by Hair et al. (2006), as cited by Jeswani (2016):

a. Remove the items that do not have factor loadings more than 0.5.

b. Items with value of more than 2 will be dropped in standardized residual covariances.

c. Items with value greater than 20 must be dropped in modification index.

First, a look at all the loadings based on the standardized estimates showed values beyond 0.5 threshold. Second, upon investigating the standardized residual covariances, Perceived Behavior manifested values more than 2 ; hence, this indicator is removed. Third, a look into the modification indices suggested drawing covariances (double-headed arrow) for variables with high values. As suggested in the modification indices, some error estimates were correlated. After undergoing the specification process, the modified model was tested again and the results showed a better goodness of fit of the model. Figure 3 shows the modified model. The goodness of fit indexes satisfied the threshold requirements- CMIN / df $=1.863$, $\mathrm{GFI}=0.966, \mathrm{NFI}=0.943, \mathrm{CFI}=0.972, \mathrm{TLI}=0.960, \mathrm{IFI}=0.980, \mathrm{PCFI}=0.267$ and $\mathrm{PNFI}=$ 0.265 . These indices meant there was a good fit to the observed data. Also, the paths between latent variables were significant. Hence, in this modified model, the mediating effect of Workplace Spirituality between Emotional Intelligence and Change Readiness is established. Moreover, the paths of Emotional Intelligence to Workplace Spirituality, Workplace Spirituality to Change Readiness, and Emotional Intelligence to Change Readiness are also established.

\subsubsection{Hypothesis Testing: Structural Equation Modelling}

Four hypotheses were proposed to determine the causal relationship between Emotional Intelligence and Workplace Spirituality, Workplace Spirituality and Change Readiness, 
Emotional Intelligence and Change Readiness, and the mediating effect of Workplace spirituality. A look into the regression weights of the standardized estimates, as shown in Figure 3, revealed the Squared Multiple Correlation (R2) of 0.17 (17\%) for workplaces spiritualty and $0.42(42 \%)$ for Emotional Intelligence. Further, the estimates indicate that Emotional Intelligence contributes $84 \%$ and $42 \%$ to Workplace Spirituality. However, Workplace Spirituality contributes only $11 \%$ to Change Readiness.

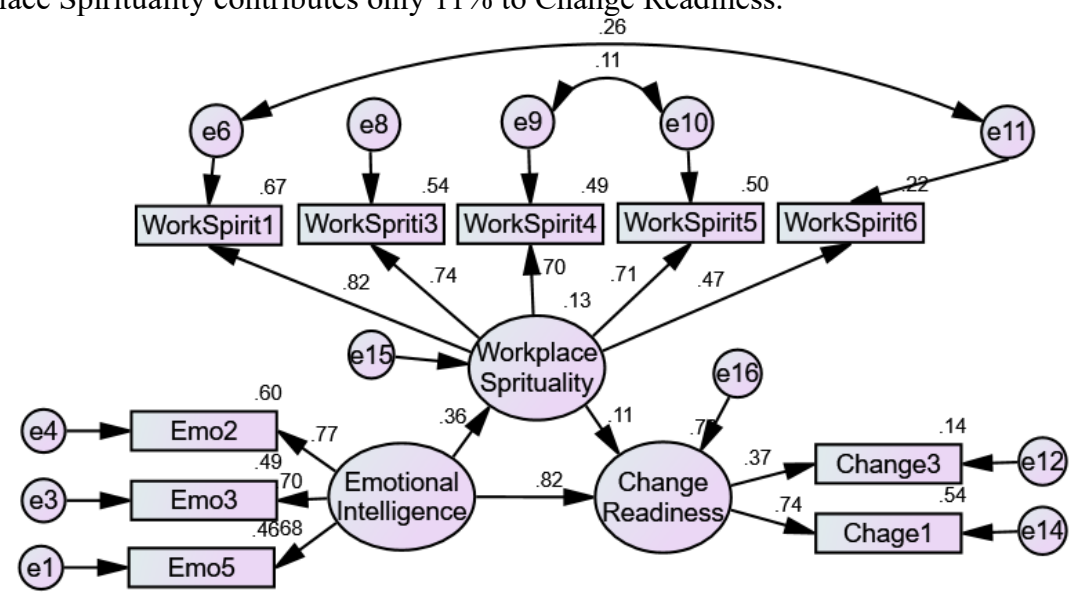

Fig. 3. Modified Model(Standardized Estimates)

Table 12. Regression Weights: (Group number 1 - Default model)

\begin{tabular}{llccccc}
\hline \multicolumn{1}{c}{} & & Estimate & S.E. & C.R. & P & Label \\
\hline WorkplaceSp $<---$ & Emotional In & .262 & .054 & 4.832 & $* * *$ & \\
Change Read $<---$ & WorkplaceSp & .130 & .086 & 1.501 & .133 & \\
Change Read <--- & Emotional In & .672 & .076 & 8.806 &.$* * *$ & \\
\hline
\end{tabular}

Furthermore, the unstandardized regression coefficients indicate the amount of change in the dependent variable/endogenous variable for each unit change of the independent variable/exogenous variable. Looking into the unstandardized regression estimates, as shown in Table 12, the findings revealed that, with a one-unit increase in Emotional Intelligence, it would decrease Workplace Spirituality by $26.2 \%$ and increase $67.2 \%$ Change Readiness. Furthermore, the p-values of less than 0.05 affirmed the impact of Emotional Intelligence on Workplace Spirituality and Change Readiness. However, Workplace Spirituality did not show a direct effect to Change Readiness as confirmed by the p-value of 0.133 , which is higher than the 0.05 level of significance. Thus, the two hypotheses are rejected.

\subsubsection{Mediation}

In order to measure the mediating or indirect effect of Workplace Spirituality between Emotional Intelligence and Change Readiness, Sobel's statistical technique was utilized. If the z-test surpasses the t-value of 1.92 (two-tailed test at 0.05 level of significance), the mediating effect is realized. The formula an $\mathrm{x} \mathrm{b}$ is used to determine the indirect impact, where an is the path coefficient of the link between the independent and mediator variables and $\mathrm{b}$ is the path 
coefficient of the relationship between the mediator variable and the dependent variable. Then, using the Sobel test, the significance level of the z-test was calculated:

$\mathrm{z}=\mathrm{abb} 2 \mathrm{SEa} 2+\mathrm{a} 2 \mathrm{SEa} 2$

Where SEa represents the standard error (SE) of the relationship between independent and mediator variables, and SEb represents the standard error (SE) of the relationship between mediator and dependent variables. Based on the result, as shown in the Table 12, the estimates between emotional intelligence and workplace spirituality is .262 and the standard error of 0.054 . For the estimates between Workplace Spirituality and Change Readiness is .130 and the standard error of 0.086 . Using the $\mathrm{z}$ formula, the results yielded a $\mathrm{z}$-test value of 2.40 which is above the 1.96 threshold. It means that Workplace Spirituality has a mediating effect between Emotional Intelligence and Change Readiness. Hence, the null hypothesis is rejected.

\subsection{Discussion}

Results of the EFA for Workplace Spirituality produced five (5) factors: Understanding Self and Others, Responsibilities of Oneself at Work, Giving Meaning, Purpose and Personal Growth, and Meditation and Reflection. First, the teachers viewed their Workplace Spirituality based on how they understand themselves and others, such as working together to resolve conflicts and care about their spiritual health and others. In connection to this, Workplace Spirituality instills past practices of interconnectivity and a sense of trust between individuals who are a part of a specific work process, which later activate cooperative emotions and lead to an overall organizational culture that is driven by motivation, exemplified by a positive response, and unity and harmony among the individuals, thereby uplifting individual performance and assisting organizational excellence [22, 23].

Second, the teachers viewed their Workplace Spirituality based on their inner responsibilities at work, such as being responsible for their behavior and growth. For teachers, growing and making a difference are some of their duties that could help themselves or the people they work with. Indeed, when teachers understand themselves and others, they create a sense of obligation and commitment at work on which building rapport and valuing oneself are developed [21].

Third, the teachers viewed their Workplace Spirituality as giving meaning because they feel that their presence gives meaning to others and to work. Work that is meaningful exhibits the concept that individuals seek significance in their jobs. The notion of meaningful work refers to cognitive employment that satisfies people by linking them to a more significant cause and providing them with items they consider essential in life. [21].

Fourth, the teachers viewed their Workplace Spirituality based on their purpose and personal growth. This is likely relatable to the second factor, yet this differs from the external factors affecting their goals, such as their superiors, work nature, and motivation in working. Furthermore, workplace spirituality focuses on the themes of tolerance, patience, interconnection, purpose, and the mind's acceptance of organizational rules, all of which are interwoven to create personal values [22].

Lastly, the teachers viewed their Workplace Spirituality based on giving importance to meditation and reflection of their lives. Teachers find time to reflect and meditate amidst the hectic schedule since it is one of their needs that they cannot leave behind [21].

For Emotional Intelligence, three factors were identified- Self-regulation, Interpersonal Effectiveness, and Openness. First, the teachers viewed their Emotional Intelligence based on 
their self-regulated [19] Self-regulation is defined as the ability to be adaptable, cope with change, and manage conflict. It also relates to defusing tense situations, understanding how one's actions effect others, and taking responsibility for one's actions [30]. Teachers, since they are self-controlling, let their anger out fast so that it does not damage them, and they find it simple to deal with tough individuals. Emotional management is important because it may boost trust, loyalty, and commitment, as well as promote efficiency, creativity, and performance in both individual and organizational settings [35].

Second, teachers viewed Emotional Intelligence based on their interpersonal effectiveness, such as empathizing with someone's problem or reconciling things. Empathy, the ability to understand how others are feeling, is critical to emotional intelligence. However, it involves more than just recognizing the emotional states of others [30]. Emotional Intelligence also has an impact on a person's understanding of a conflict scenario, decision-making ability, and ultimate choices and conclusions [33]. As a result, successfully and responsibly managing conflict is mostly dependent on an individual's self-management abilities and capacity to identify constructive solutions. Such solutions may necessitate compromise, which is where EI comes in [34]. Lastly, teachers viewed their Emotional Intelligence based on their openness towards other people. Teachers face emotional stress, the inadequacy of feelings, loss of vigor in teaching, and the lack of motivation that may lead to poor performance [8]. When instructors' emotions are appropriately handled, they may foster trust, loyalty, and dedication, as well as promote efficiency, inventiveness, and accomplishment in both individual and organizational settings [35].

For Change Readiness, two (2) factors were produced- Self-efficacy and Uncertainty. First, teachers viewed Change Readiness based on their Self-Efficacy. This factor refers to recognizing the opportunities and possibilities and gaining that drive to be unaffected amidst changes. Carter (2016) discloses that being change-ready produces better performance than others as they successfully integrate resiliency and adaptability. If employees show a willingness to change, the chances of success are high and vice versa [44].

Second is Uncertainty. This factor refers to the possibility that change may become terrifying and uncomfortable, and the feeling of uncertainty may dominate, especially when a person is unaware of what will happen. A major problem as change occurs is the resistance of employees to change. For example, teachers resist change since work becomes more fastpaced, overwhelming; thus, resulting to decreased satisfaction and high turnover [42]. People also resist change because they fail to perceive the benefits and good aspects of it. Instead, they concentrate on what they are losing. Change Readiness assesses an individual's ability to adjust to change on a continuous basis, resulting in a competitive advantage, long-term performance, and risk avoidance [43]. Finally, every change causes employee pain since they are required to leave their comfort zone. Because they are moving from known to unknown settings, it is natural for employees to demonstrate resistance to change [44].

Using structural equation modeling (SEM), the findings significantly influenced Emotional Intelligence on Workplace Spirituality. It supports the Emotional Intelligence theory, which argues that having high emotional intelligence can affect work performance and develop a sense of meaning towards oneself, others, and work. This is supported by an explanation of Marques, Allevato, and Holt (2008) [27] Employees with high levels of emotional intelligence are more emotionally and spiritually linked to their jobs and organizations. resulting in higher group performance. In the context of public school teachers, the factors of Emotional Intelligence taken together have shown a positive influence on their workplace spirituality. Emotional Intelligence factors have shown a positive influence on their Workplace Spirituality. 
The findings also revealed that having high Emotional Intelligence can affect the Change Readiness of teachers. The Emotional Intelligence theory also supports this, explaining its significance to job performance and how to deal with changes. The five (5) components of Emotional Intelligence help teachers to be equipped internally and externally to the different challenges and changes that may come. Being self-aware, self-regulated, and motivated establishes a positive outlook in the future. Showing empathy towards others and developing a positive relationship can make certain adjustments much more manageable. Steigenberger (2015)[9] discloses that EI is an essential aspect in implementing change in an organization. In addition, teachers' Emotional Intelligence affects their comfort level, self-efficacy, and job satisfaction level, enhancing social relationships with students [49]. In the context of public schools, the factors of Emotional Intelligence taken together have shown a positive influence on their Change Readiness.

However, the last findings revealed that there is no significant influence of Workplace Spirituality on Change Readiness. It means that it did not conform to the spiritual intelligence theory that one's spiritual intelligence would enable an individual to be less fearful, more accustomed to relying on himself, and be more eager to face challenges and discomforts [20]. It appeared that in the context of the respondents their Workplace Spirituality, measured in terms of Understanding Self and Others, Responsibilities of Oneself at Work, Giving Meaning, Purpose and Personal Growth. Meditation and reflection did not show a direct effect on Change Readiness. It can be noted that strengthening Workplace Spirituality is a big challenge, specifically in public schools. In this modern era, Workplace Spirituality has to be strengthened since various changes happen consistently, improving organizational effectiveness as employees tried to resist it, yet it is impossible [37].

Surprisingly, the mediating effect of Workplace Spirituality between Emotional Intelligence and Change Readiness was established. This means that Workplace Spirituality showed an indirect effect between these two. Though Workplace Spirituality did not show any effect on Change Readiness, there is an indirect effect. This means that in determining Change Readiness, they will not only look into their Emotional Intelligence because it is mediated. Hence, Workplace Spirituality must also be considered. Moreover, being change-ready means having positive thoughts that change may benefit them and the organization [37]. Garg (2017) [62] states that to build trust and create an environment ready to take higher responsibilities, one must strengthen his spirituality. Moreover, spirituality plays an essential role in workplaces and schools and is a fundamental element to boost the performance of employees [ (Subramanian \& Panchanatham, 2016)[14], and when they find meaning in their work, they become more engaged [13].

\section{Conclusions}

Based on the findings, the following conclusions are drawn:

a. The results identified the underlying factors for Workplace spirituality, Emotional Intelligence, and Change Readiness. In Workplace spirituality (WS), five (5) factors were identified: Understanding Self and Others, Responsibilities of Oneself at Work, Giving Meaning, Purpose and Personal Growth, and Meditation and Reflection. In Emotional Intelligence (EI), three (3) factors were identified, namely, Self-regulation, Interpersonal Effectiveness, and Openness. And in Change Readiness, two (2) factors were identified: Self-efficacy and Uncertainty. 
b. Using Structural Equation Modelling (SEM), findings revealed a significant influence of Emotional Intelligence on Workplace Spirituality. It shows that in the context of public school teachers in Davao del Sur, Emotional Intelligence factors have shown a positive influence on their Workplace Spirituality. The findings also showed a significant influence of Emotional Intelligence on Change Readiness. In other words, in the context of public school teachers, factors of Emotional Intelligence have shown a positive influence on their Change Readiness. Moreover, these two findings did support the theory of Emotional Intelligence. However, a non-significant influence of Workplace Spirituality on Change Readiness was found, and it did not support the theory on spiritual intelligence. It appeared that in the context of the public school teachers, their Workplace Spirituality measured in terms of Understanding Self and Others, Responsibilities of Oneself at Work, Giving Meaning, Purpose and Personal Growth, and Meditation and Reflection, did not show a direct effect towards Change Readiness.

c. Moreover, based on the result of the study, there is a mediating effect of Workplace Spirituality between Emotional Intelligence and Change Readiness. If the public schools would like to determine teachers' Change Readiness, they will not only look into their Emotional Intelligence because it is mediated. Hence, they also need to consider the mediating variable, which is Workplace Spirituality.

\section{Recommendations}

The following suggestions are made based on the study's findings:

a. To improve programs addressing Workplace Spirituality, Emotional Intelligence, and Change Readiness of teachers, the underlying factors identified in the model can be used as major considerations. Moreover, they can also focus on the identified variables removed from the model like Self-awareness for Workplace Spirituality, Motivating Oneself and others and Self-awareness for Emotional Intelligence, and Adaptability for Change Readiness. This will help the public schools assess the weak variables that can be refined and developed.

b. Programs on self-regulation, interpersonal effectiveness, and openness are highly recommended since it positively influences Change Readiness and Workplace Spirituality.

c. The non-significant influence of Workplace Spirituality on change readiness is a big challenge to the administrators of the Division of Davao del Sur. As the public schools in charge, it must be considered one of their priorities to see to it that spirituality in the workplace is developed and deepened, most especially teachers face various challenges due to unprecedented changes in the educational system.

d. For future researches, a study on the factors affecting teachers' Workplace Spirituality is suggested. Researchers can also address the weaknesses found in the current study's data collection techniques and sample size.

\section{References}

[1] Puertas Molero, P., Zurita Ortega, F., Ubago Jiménez, J. L., \& González Valero, G. (2019). Influence of emotional intelligence and burnout syndrome on teachers wellbeing: A systematic review. Social Sciences, $8(6)$, https://doi.org/10.3390/socsci8060185 
[2] Kondakci, Y., Beycioglu, K., Sincar, M., \& Ugurlu, C. T. (2017). Readiness of teachers for change in schools. International Journal of Leadership in Education, 20(2), 176197. https://doi.org/10.1080/13603124.2015.1023361

[3] Al Salami, M. K., Makaela, C. J., \& de Miranda, M.A . (2017). Assessing changes in teachers' attitudes toward interdisciplinary STEM teaching. International Journal of Technology and Design ～Education, 2017,27.1:63-88.

[4] Howard, S. K., Tondeur, J., Siddiq, F., \& Scherer, R. (2020). Ready, set, go! Profiling teachers' readiness for online teaching in secondary education. Technology, Pedagogy and Education, 1-18. $\quad$ https://doi.org/10.1080/1475939X.2020.1839543

[5] Hernando-Malipot, M. (2019). Has Change Come to Philippine Education? https://news.mb.com.ph/2019/05/18/has-change-come-to-philippine-education/

[6] Callo, E. C., \& Yazon, A. D. (2020). Exploring the factors influencing the readiness of faculty and students on online teaching and learning as an alternative delivery mode for the new normal. Universal Journal of Educational Research, 8(8), 3509-3518.

[7] Robosa, J., Paras, N. E., Perante, L., Alvez, T., \& Tus, J. (2021). The Experiences and Challenges Faced of the Public School Teachers Amidst the COVID-19 Pandemic: A Phenomenological Study in the Philippines. International Journal of Advance Research And Innovative Ideas In Education, 7(1), 1342-1361.

[8] Colomeischi, A. A. (2015). Teachers burnout in relation with their emotional intelligence and personality traits. Procedia-Social and Behavioral Sciences, 180, 1067-1073. https://doi.org/10.1016/j.sbspro.2015.02.207

[9] Steigenberger, N. (2015). Emotions in sensemaking: a change management perspective. Journal of Organizational Change Management, 28(3), 432-451. https://doi.org/10.1108/JOCM-05-2014-0095

[10] Grobler, B., Moloi, C., \& Thakhordas, S. (2017). Teachers' perceptions of the utilization of Emotional Intelligence by their school principals to manage mandated curriculum change processes. Educational Management Administration \& Leadership, 45(2), 336-355. https://doi.org/10.1177\%2F1741143215608197

[11] Alarcon, G. M. (2011). A meta-analysis of burnout with job demands, resources, and attitudes. Journal of vocational behavior, 79(2), 549-562. https://doi.org/10.1016/j.jvb.2011.03.007

[12] Okeke, C. I. O., \& Dlamini, C. C. (2013). An empirical study of stressors that impinge on teachers in secondary schools in Swaziland. South African Journal of Education, 33(1). https://doi.org/10.15700/saje.v33n1a607

[13] Izak, M. 2012. "Spiritual Episteme: Sensemaking in the Framework of Organizational Spirituality." Journal of Organizational Change Management 25 (1): 24-47. https://doi.org/10.1108/09534811211199583

[14] Subramaniam, M., \& Panchanatham, N. (2016). Influence of Personality On Workplace Spirituality.

[15] Pawar, B. S. (2016). Workplace spirituality and employee well-being: An empirical examination. Employee Relations, 38(6), 975-994. https://doi.org/10.1108/ER-11-20150215

[16] Gupta, M., Kumar, V., \& Singh, M. (2014). Creating satisfied employees through workplace spirituality: A study of the private insurance sector in Punjab (India). Journal of business ethics, 122(1), 79-88. https://doi.org/10.1007/s10551-0131756-5 
[17] Petchsawang, P., \& McLean, G. N. (2017). Workplace spirituality, mindfulness meditation, and work engagement. Journal of Management, Spirituality \& Religion, 14(3), 216-244.

[18] Goleman, D. (1995). Emotional intelligence. New York: Bantam Books.

[19] Salovey, P., \& Mayer, J. D. (1990). Emotional intelligence. Imagination, Cognition and Personality, 9, $185-211$.

[20] Selman, V., Selman, R. C., Selman, J., \& Selman, E. (2011). Spiritual-intelligence/quotient. College Teaching Methods \& Styles Journal (CTMS),1(3), 23-30.

[21] Duchon, D., \& Plowman, D. A. (2005). Nurturing the spirit at work: Impact on work unit performance. The leadership quarterly, 16(5), 807-833. https://doi.org/10.1016/j.leaqua.2005.07.008

[22] Afsar, B., \& Rehman, M. (2015). The relationship between workplace spirituality and innovative work behavior: The mediating role of perceived personorganization fit. Journal of Management, $\quad$ Spirituality \& Religion, 12(4), 329-353. https://doi.org/10.1080/14766086.2015.1060515

[23] Kumar, S. (2018). A Study of Perceived Workplace Spirituality of School Teachers. Psychological Thought, 11(2), 212-223. http://dx.doi.org/10.5964/psyct.v11i2.298

[24] Ashmos, D. P., \& Duchon, D. (2000). Spirituality at work: A conceptualization and measure. Journal of management inquiry, 9(2), 134-145. https://doi.org/10.1177\%2F105649260092008

[25] Pfeffer, J. (2010). Building sustainable organizations: The human factor. The Academy of Management Perspectives, 24(1),34-45. doi:10.5465/amp.24.1.34

[26] Rajappan, S., Nair, R. S., Kirupa, P. M., \& Sivakumar, V. (2017). Exploring the effect of workplace spirituality on job embeddedness among higher secondary school teachers in Ernakulam district. Cogent Business \& Management, 4(1)http://dx.doi.org/10.1080/23311975.2017.1334419

[27] Marques, J. (2005). Socializing a capitalistic world: Redefining the bottom line. Journal of American academy of business, 7(1), 283.

[28] Parumasur, S.B., \& Govender, P. (2016). Empirical study on the link between corporate citizenship behavior and spirituality in the corporate environment. Risk Governance \& Control: Financial Markets \& Institutions, 6(3), 81-92. https://doi.org/10.22495/rcgv6i3c2art11

[29] Ghanizadeh, Afsaneh, and Nahid Royaei. 2015. Emotional facet of language teaching: Emotion regulation and emotional labor strategies as predictors of teacher burnout. International Journal of Pedagogies and Learning 10: 139-50. https://doi.org/10.1080/22040552.2015.1113847

[30] Cherry, K. (2018). 5 Components of emotional intelligence. Very Well Mind. https://www.verywellmind.com/components-of-emotional-intelligence-2795438

[31] Barrios, M. (2016). Comparing Emotional Intelligence Levels in Teachers of the Year in Elementary School, Middle School, and High School and How Their Emotional Intelligence Traits Are Exhibited in the Classroom (Order No. 10108344). Available from Publicly Available Content Database. (1793669105). https://www.proquest.com/dissertations-theses/comparing-emotional-intelligencelevels-teachers/docview/1793669105/se-2?accountid=37714

[32] Yoo, M. S. (2016). The influences of workplace spirituality and emotional intelligence on the organizational citizenship behavior for clinical nurses. The Korean Journal of Health Service Management, 10(2), 59-70. https://doi.org/10.12811/kshsm.2016.10.2.059 
[33] Hopkins, M. M., \& Yonker, R. D. (2015). Managing conflict with emotional intelligence: Abilities that make a difference. Journal of Management Development. https://doi.org/10.1108/JMD-04-2013- 0051

[34] Schlaerth, A., Ensari, N., \& Christian, J. (2013). A meta-analytical review of the relationship between emotional intelligence and leaders' constructive conflict management. Group Processes \& Intergroup Relations, 16(1), 126-136. https://doi.org/10.1177\%2F1368430212439907

[35] Lakshmi, K. N., \& Rao, K. S. (2018). A Study on Role of Emotional Intelligence on Employee Performance. International Journal of Civil Engineering and Technology, 9(3).

[36] Smollan, R. K. (2015). Causes of stress before, during and after organizational change: a qualitative study. Journal of Organizational Change Management. https://doi.org/10.1108/JOCM-03-2014-0055

[37] Inandi, Y., \& Giliç, F. (2016). Relationship of Teachers' Readiness for Change with Their Participation in Decision Making and School Culture. Educational Research and Reviews, 11(8), 823-833.

[38] Wanberg, C. R., \& Banas, J. T. (2000). Predictors and outcomes of openness to changes in a reorganizing workplace. Journal of applied psychology, 85(1), 132. https://psycnet.apa.org/doi/10.1037/0021-9010.85.1.132

[39] Adil, M.S. (2016),Impact of change readiness on commitment to technological change, focal, and discretionary behaviors: Evidence from the manufacturing sector of Karachi, Journal of Organizational Change Management, Vol. 29 No. 2, pp. 222-241. https://doi.org/10.1108/JOCM-11- 2014-0198

[40] Bouckenooghe, D., \& Devos, G. (2007). Psychological change climate as a catalyst of readiness for change: A dominance analysis. Departement of Management and Entrepreneurship Ghent University.

[41] Oreg, S. (2003). Resistance to change: Developing an individual differences measure. Journal of Applied Psychology, 88(4), 680-693. https://doi.org/10.1037/00219010.88.4.6800

[42] Hargreaves, A. (2003). Teaching in the knowledge society: Education in the age of insecurity. Milton Keynes: Open University Press.

[43] Sharma, T., \& Singh, S. (2018). Relationship of emotional intelligence with cultural intelligence and change readiness of Indian managers in the service sector. Journal of Organizational Change Management. https://doi.org/10.1108/JOCM-05-20170193

[44] Thakur, R. R., \& Srivastava, S. (2018). From resistance to readiness: the role of mediating variables. Journal of Organizational Change Management, 31(1), 230-247. https://doi.org/10.1108/JOCM-06-2017-0237

[45] Daniel, J. L. (2015). Workplace spirituality and stress: Evidence from Mexico and US. Management Research Review.

[46] Daniel, J. L., \& Chatelain-Jardon, R. (2015). The relationship between individual spirituality, organizational commitment and individual innovative behavior. Management Research and Practice, 7(1), 5. https://doi.org/10.1108/MRR07-2013-0169

[47] Gotsis, G., \& Kortezi, Z. (2008). Philosophical foundations of workplace spirituality: A critical approach. Journal of Business Ethics, 78, 575-600. https://doi.org/10.1007/s10551-007-9369-5 
[48] Naldoza, N. (2020). Online Teaching and Learning Preparedness Survey. https://docs.google.com/forms/d/e/1FAIpQLSfU_i57h19jgASOby9PeWZtrpNeYwFIc 8ApdBkh FAcOxj5euA/viewform.

[49] Abiodullah, M., Dur-e-Sameen, \& Aslam, M. (2020). Emotional Intelligence as a Predictor of Teacher Engagement in Classroom. Bulletin of Education and Research, 42(1), $127 . \quad$ https:/www.proquest.com/scholarly-journals/emotionalintelligence-as-predictor- teacher/docview/2435554661/se-2?accountid=37714

[50] Daggett, W. R. (2014). Rigor/relevance framework: A guide to focusing resources to increase student performance. International Center for Leadership in Education, 17.

[51] Hassan, S. N. S., Robani, A., \& Bokhari, M. (2015). Elements of Self-Awareness Reflecting Teachers' Emotional Intelligence. Asian Social Science, 11(17), 109.

[52] Iqbal, Q., \& Hassan, S. H. (2016). Role of workplace spirituality: Personality traits and counterproductive workplace behaviors in banking sector. International Journal of Management, Accounting and Economics, 3(12), 806-821.

[53] Mayer, J. D., Caruso, D. R., \& Salovey, P. (2016). The ability model of emotional intelligence: Principles and updates. Emotion Review, 8(4), 290-300.

[54] Schutte, N. S., \& Malouff, J. M. (2011). Emotional intelligence mediates the relationship between mindfulness and subjective well-being. Personality and individual differences, 50(7), 1116-1119. https://doi.org/10.1016/j.paid.2011.01.037

[55] Carter, A., Tobias, J., \& Spiegelhalter, K. (2016). Mindfulness in organisations.

[56] Ranta, M. (2014). The impact of trust in management and quality of change communication on readiness for change (Doctoral dissertation).

[57] Wong, T. M. (2018). Teaching innovations in Asian higher education: perspectives of educators. Asian Association of Open Universities Journal.

[58] Calderon, J., \& Gonzales, E. (1993). Methods of Research and Thesis Writing. Mandaluyong: National Bookstore.

[59] Haig, B. D. (2005). Exploratory factor analysis, theory generation, and scientific method. Multivariate Behavioral Research, 40(3), 303-329.

[60] Kaplan, D. (2008). Structural equation modeling: Foundations and extensions (Vol. 10). Sage Publications. 